\title{
Мультикомпонентна стратегія хірургії білобарного метастатичного ураження печінки колоректальним
} \section{раком}

\author{
Національний інститут раку, Київ \\ Одержано 09.10.2019 \\ Підиисано до друку 08.11.2019
}

DOI: $10.32471 /$ clinicaloncology.2663-466X.40.23077

\begin{abstract}
Актуальність. Дотепер маловивченими є результати паренхімозберігаючої стратегії при локалізації метастатичних утворень у важкодоступних сайтах печінки з точки зору хірургічної анатомії органа (праве венозне ядро, портальні та кавальні ворота печінки, паракавальна та каудальна частини 1-го сегмента). Мета. Вивчити онкологічну та хірургічну безпеку паренхімозберігаючої хірургічної стратегії у хворих із метастатичним ураженням важкодоступних сайтів печінки. Матеріал та методи. Виконано ретроспективний аналіз результатів хірургічного та комбінованого лікування хворих із білобарним метастатичним ураженням печінки колоректальним раком. Залежно від локалізації метастатичних вогнищ хворих умовно розподілили на 2 групи: «периферичні» (n=38), до якої віднесли пацієнтів із переважним ураженням лівої латеральної секції $(S e g$ 2,3) та задньої секції (Seg 6,7), спігелієвої частини Seg 1; «центральні» (n=107) - хворі із метастатичним ураженням портальних та кавальних воріт печінки, передньої секції (Seg 5,8), 4-го сегмента, паракавальної частини Seg 1. Результати. Центральні резекції за принципами збереження паренхіми печінки потребували частішого використання принципів xipypriї R1 vascular detachment, що виконали у 23,6 та 4,6\% випадках хворим групи із центрально та периферично локалізованими метастазами відповідно (p<0,001). Післяопераційні тяжкі ускладнення (III ступеня за класифікацією Clavien - Dindo) становили 7,8 та 4,6\% відповідно для груп порівняння $(p=0,23)$. Рівень загальної кумулятивної 3-річної виживаності в групах хворих становив 38 та $42 \%$ відповідно для групи центрально та периферично розташованих метастатичних вогнищ ( $(=0,44)$. Висновки. Вважаємо, що застосування R1 vascular detachment у поєднанні з сучасними схемами поліхіміотерапії може бути альтернативним методом, який зменшить коґорту нерезектабельних хворих із білобарним метастатичним ураженням печінки.
\end{abstract}

Ключові слова: R1 vascular detachment; паренхімозберігаюча резекція печінки; інтраопераційна ультразвукова навігація; важкодоступні сайти печінки.

\section{ВСТУП}

Доцільність виконання широкого відступу від краю пухлинного вогнища при резекціях печінки у пацієнтів із метастазами колоректального раку (мКРР) фахівці активно обговорюють впродовж останніх 20 років. Тактика відступу $\geqslant 1 \mathrm{~cm}$ пояснювалася результатами аналізу декількох провідних центрів, що прогнозували достовірно гіршу виживаність серед пацієнтів з меншим відступом від краю пухлини [1]. Група хірургів на чолі з M.I. D’Angelica впровадила описану тактику і протягом останніх 10 років продовжують публікувати підтвердження доцільності широкого відступу від краю метастатичного вогнища, наводячи дані, що відступ більш ніж на 1 см дозволяє покращити віддалені результати лікування [2].

Майже одночасно низка спеціалізованих хірургічних центрів почали відстоювати хірургічну практику, яка передбачала відступ 1 мм. Нещодавно ці самі автори опублікували дані, що R1 має менше прогностичне значення порівняно з біологічними особливостями первинної пухлини та ії метастазів [3, 4]. Таке різноманіття доказів, що публікується авторами, спонукало до активного пошуку єдиного правильного рішення, який триває дотепер. Слід відзначити, що більшість публікацій на тему результатів резекції множинних метастазів схожі в підході щодо відступу, спеціалісти стверджують, що використовували мінімальний край відступу з метою максимального збереження паренхіми печінки.

У 2016 p. R. Adam та співавтори довели, що паренхімозберігаюча хірургія правої частки печінки має стати золотим стандартом для хворих із мКРР, оскільки сам факт видалення правої частки печінки призводить до хронічної печінкової недостатності, погіршення якості життя та достовірного зменшення його тривалості [5]. Водночас активно впроваджується тактика одноетапних У3-контрольованих паренхімозберігаючих резекцій печінки, альтернативної тактики при білобарному метастатичному ураженні мКРР, що передбачає паренхімозберігаюче видалення всіх метастатичних вогнищ в печінці за один етап [6]. Останній підхід також вважається адаптованою методикою cherry-picking surgery, яка використовувалася при видаленні субкапсульних метастазів у печінці [7]. G. Torzilli та співавтори розширили показання до УЗ-контрольованих паренхімозберігаючих резекцій печінки та адаптували цю технологію для видалення глибоко розташованих метастатичних вогнищ у печінці [8].

Таким чином, останній консенсус щодо стратегії хірургічного лікування мКРР було опубліковано у 2016 р., у ньому чітко сформульовано, що відступ $\geqslant 1$ мм є достатнім та безпечним [9]. Проте дотепер маловивченими залишаються результати паренхімозберігаючої стратегії при локалізації метастатичних утворень у важкодоступних сайтах печінки з точки зору хірургічної анатомії органа (праве венозне ядро, портальні та кавальні ворота печінки, паракавальна та каудальна частини 1-го сегмента).

Тому метою нашої роботи було вивчити онкологічну та хірургічну безпеку паренхімозберігаючої хірургічної стратегії у хворих із метастатичним ураженням важкодоступних сайтів печінки.

\section{МАТЕРІАЛ ТА МЕТОДИ}

Виконано ретроспективний аналіз результатів хірургічного та комбінованого лікування хворих із білобарним метастатичним ураженням печінки колоректальним раком (КРР). Досліджувалися хворі $(\mathrm{n}=145)$ з мКРP (pT1-4N0-2M0-1 рак ободової кишки і рT1-3N0-2M0-1 рак прямої кишки), які були оперовані в умовах Національного інституту раку в період з січня 2015 р. до вересня 2019 р. (табл. 1). Хворих, залежно від локалізації метастатичних вогнищ, умовно поділили на 2 групи: «периферичні» ( $\mathrm{n}=38)$, до якої віднесли пацієнтів із переважним ураженням лівої латеральної секції (Seg 2,3) та задньої секції (Seg 6,7), спігелієвої частини Seg 1 ; «центральні» $(\mathrm{n}=107)-$ хворі з метастатичним ураженням портальних та кавальних воріт печінки, передньої секції (Seg 5,8), 4-го сегмента, паракавальної частини Seg 1. 
Таблиця 1. Характеристика хворих

\begin{tabular}{lcc}
\hline \multicolumn{1}{c}{ Показник } & 3начення & $\%$ \\
\hline Вік, років & $67,3 \pm 1,5$ & \\
Індекс маси тіла & $28,3 \pm 2,9$ & \\
Стать (чоловіки/жінки) & $81 / 64$ & $55,8 / 44,2$ \\
Статус метастазування в печінку (усM0/ycM1) & $13 / 132$ & $8,9 / 91,1$ \\
Локалізація первинної пухлини & $44 / 101$ & $30,3 / 69,7$ \\
(пряма/ободова кишки) & & \\
Статус регіонарних лімфатичних вузлів pN (+/-) & $38 / 107$ & $26,2 / 73,8$ \\
Статус хворого за шкалою Американської & $96 / 49$ & $66,2 / 33,8$ \\
асоціації анестезіологів (АSA) (I-ІІ/ІІІ) & & \\
Обстеження та лікування: & & \\
Комп'ютерна томографія (KT) & 145 & 100,0 \\
Магнітно-резонансна томографія (MPT) & 127 & 87,6 \\
Позитронно-емісійна томографія (ПЕТ-КТ) & 14 & 9,6 \\
Неоад'ювантна хіміотерапія & 35 & 24,2 \\
Ад'ювантна хіміотерапія & 142 & 97,3 \\
\hline
\end{tabular}

У кожному клінічному випадку було застосовано мультидисциплінарний розбір, участь у якому брали хірургионкологи, клінічні онкологи і променеві терапевти. Рутинно використовували КТ з внутрішньовенним контрастуванням грудної, черевної порожнин і порожнини малого таза та МРТ. ПЕТ-КТ використовували тільки за підозри на наявність метастатичного ураження інших органів/сайтів, а також у складних клінічних випадках.

Хірургічна техніка передбачала виконання радикальної резекції з максимально можливим збереженням паренхіми і забезпеченням радикального відступу від краю пухлини $(\geqslant 1$ мм). У випадках множинних та глибоко розташованих вогнищ операція супроводжувалася ультразвуковою навігацією для розмітки осередків щодо магістральних печінкових вен і глісонових структур, також з метою виявлення метастазів, які неможливо визначити пальпаторно. Техніка ішемії передбачала застосування класичного та селективного маневру Прінгла (20 хв - ішемія, 5 хв - реперфузія). Транссекція паренхіми виконувалася за методом crashclamp. Гемостаз резектованої паренхіми виконували за допомогою прошивання prolene 4.0, 5.0, біполярного пінцета, кліпування LT200, LT300.

Пацієнти отримували, згідно з міжнародними стандартами, ад'ювантну поліхіміотерапію. Пацієнтам з прогресуванням захворювання на тлі поліхіміотерапії резекцію печінки не виконували. Функціональні резерви печінки оцінювали за шкалами Чайлда - Туркота - П'ю і MELD. Прояви токсичності хіміотерапії реєстрували згідно з критеріями СТСАЕ 5.0. Ступінь складності гострої печінкової недостатності в післяопераційний період визначали за класифікацією Міжнародної дослідницької групи з хірургії печінки (International Study Group of Liver Surgery - ISGLS).

\section{МЕТОДИ СТАТИСТИЧНОї ОБРОБКИ}

Отримані результати піддавалися статистичному аналізу за допомогою статистики SPSS 20.0 (IBM, Армонк, штат Нью-Йорк, США). Т-тест було застосовано для оцінки різниці концентрацій у сечі 8-OhdGu між донорами та пацієнтами 3 мКРР. Статистичні тести були двосторонніми, коли $\mathrm{p}<0,05$, і вважалися статистично значимими. Виживаність хворих аналізували методом Каплана - Мейєра. Результати представлені у вигляді $\mathrm{M} \pm \mathrm{m}$.

\section{РЕЗУЛЬТАТИ}

В аналіз дослідження було включено 145 хворих з мКРР, яким проводили резекцію печінки. Групи порівняння мали достовірну відмінність за кількістю видалених метастазів $(\mathrm{p}=0,03)$. Стратифікація груп виявила, що основною відмінністю стала підгрупа пацієнтів, у яких видалили від 6 до 10 метастазів ( $<<0,001)$. Білобарне метастатичне ураження відмічали у $58(40 \%)$ випадках, у групі 3 центрально локалізованими вогнищами КРР таких хворих було менше ( $<<0,001)$ (табл. 2). У більшості оперованих пацієнтів виконали резекцію від 2 до 5 метастатичних вогнищ (47,6\%), без достовірної відмінності в групах $(\mathrm{p}=0,67)$. У 32,21 та 5 випадках було видалено в межах 6-10, $11-15$ та $\geqslant 15$ метастатичних вогнищ відповідно (див. табл. 2).
Також у $83(57,3 \%)$ хворих використовували маневр Прінгла з метою контролю притоку крові під час транссекції перенхіми. Гемотрансфузію виконували в обох групах порівняння - у $13(34,2 \%)$ та $4(10,5 \%)$ випадках відповідно для центральних та периферичних резекцій $(\mathrm{p}<0,001)$.

Таблиця 2. Характеристика резекцій печінки в групах хворих (n, \%)

\begin{tabular}{|c|c|c|c|}
\hline Показник & $\begin{array}{c}\text { Центральні, } \\
\mathrm{n}=\mathbf{3 8}\end{array}$ & $\begin{array}{c}\text { Периферичні, } \\
\text { n=107 }\end{array}$ & $\mathbf{p}$ \\
\hline $\begin{array}{l}\text { Кількість видалених метаста- } \\
\text { тичних вогнищ, медіана } \\
\text { (мінімум-максимум) }\end{array}$ & $3(1-8)$ & $7(2-19)$ & 0,03 \\
\hline \multicolumn{4}{|l|}{$\begin{array}{l}\text { Розподіл за кількістю видалених ме- } \\
\text { тастатичних вогнищ: }\end{array}$} \\
\hline 1 & $4(10,5)$ & $14(13,1)$ & 0,17 \\
\hline $2-5$ & $18(47,4)$ & $51(47,6)$ & 0,48 \\
\hline $6-10$ & $16(42,1)$ & $16(14,9)$ & $<0,001$ \\
\hline $11-15$ & - & $21(19,6)$ & 0,014 \\
\hline$\geqslant 15$ & - & $5(4,6)$ & 0,08 \\
\hline $\begin{array}{l}\text { Комбіноване видалення первинної } \\
\text { пухлини та резекція печінки }\end{array}$ & $3(7,8)$ & $9(8,4)$ & 0,46 \\
\hline $\begin{array}{l}\text { Білобарне метастатичне } \\
\text { ураження печінки }\end{array}$ & $27(71,1)$ & $31(28,9)$ & $<0,001$ \\
\hline Застосування маневру Прінгла & $38(100)$ & $45(42,1)$ & $<0,001$ \\
\hline Гемотрансфузія & $13(34,2)$ & $4(3,7)$ & $<0,001$ \\
\hline R1 vascular contact & $10(26,3)$ & $5(4,6)$ & $<0,001$ \\
\hline Тяжкі ускладнення (श्राI ступеня) & $3(7,8)$ & $5(4,6)$ & 0,23 \\
\hline Післяопераційна летальність & $1(2,6)$ & - & 0,05 \\
\hline
\end{tabular}

Також групи відрізнялися частішим та тривалішим застосуванням контролю притоку крові до печінки. Так, маневр Прінгла використовувався у $38(100,0 \%)$ та $45(42,1 \%)$ випадках відповідно для груп центрального та периферичного розташування метастатичних вогнищ $(<0,001)$. Крім того, центральні резекції за принципами збереження паренхіми печінки потребували частішого використання принципів хірургіï R1 vascular. Vascular detachment виконали у $10(23,6 \%)$ випадках хворим групи із центрально локалізованими метастазами та тільки у 5 (4,6\%) при периферичних $(\mathrm{p}<0,001)$.

Післяопераційні тяжкі ускладнення ( $\geqslant$ III ступеня за класифікацією Clavien - Dindo) становили 7,8 та 4,6\% відповідно для груп порівняння $(\mathrm{p}=0,23)$. Летальність у 30 -денний післяопераційний період була зареєстрована тільки в групі центральних резекцій, причиною якої став мезентеріальний тромбоз на 5-ту післяопераційну добу $(\mathrm{p}=0,05)$. У жодному з випадків групи центрально розташованих метастатичних вогнищ не було зареєстровано ознак гострої печінкової недостатності вище ступеня А.

Рівень загальної кумулятивної 3-річної виживаності в групах хворих становив 38 та 42\% відповідно для групи центрально та периферично розташованих метастатичних вогнищ відповідно $(\mathrm{p}=0,44)$ (рис. 1).

Клінічні приклади периферично та центрально розташованих метастатичних вогнищ представлені на рис. 2-4.

Усі представлені клінічні випадки пройшли контрольні обстеження після оперативного лікування через $\geqslant 1$ рік зінтервалом в 4 міс. На момент написання статті, за даними МРТ та КТ досліджень, свідчення на користь прогресування та/чи локального рецидиву в проєкції виконаного vascular detachment відсутні.

\section{ОБГОВОРЕННЯ}

Незважаючи на стрімкий розвиток системної хіміотерапії, видалення первинної пухлини та всіх сайтів, уражених віддаленими метастазами, залишається пріоритетним у показниках виживаності таких хворих. Більш ніж 50\% хворих із мКРР із резекцією печінки в анамнезі з приводу їі метастатичного ураження мають ризик повторного метастатичного ураження органа, що вимагає лікування хіміопрепаратами 2-їлінії і резекції. Принцип широкого краю відступу (1 см) при резекціях метастатичних вогнищ КРР в печінці змушував хірургів виконувати «великі» та розширені гепатектомії. Така тактика в більшості випадків призводить до високої частоти тяжких ускладнень, зокрема гострої печінкової недостатності в ранній післяопераційний період та синдрому малої печінки на більш пізніх термінах, 


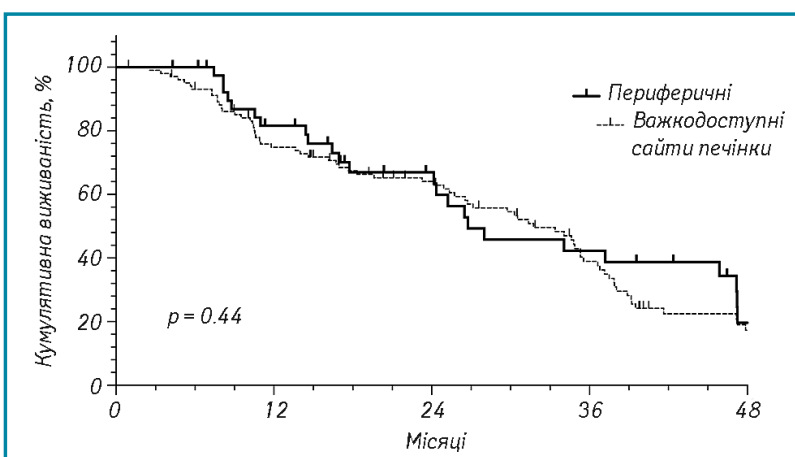

Рис. 1. Графічне зображення загальної кумулятивної виживаності 145 оперованих хворих на мКРР із білобарним метастатичним ураженням печінки: група «периферичні» - хворі, які мали периферично розташовані метастатичні вогнища; важкодоступні сайти печінки - метастатичні вогнища, локалізовані вцентральних сегментахпечінки та/або мали судинний контакт з її судинними структурами 1-3-го порядку

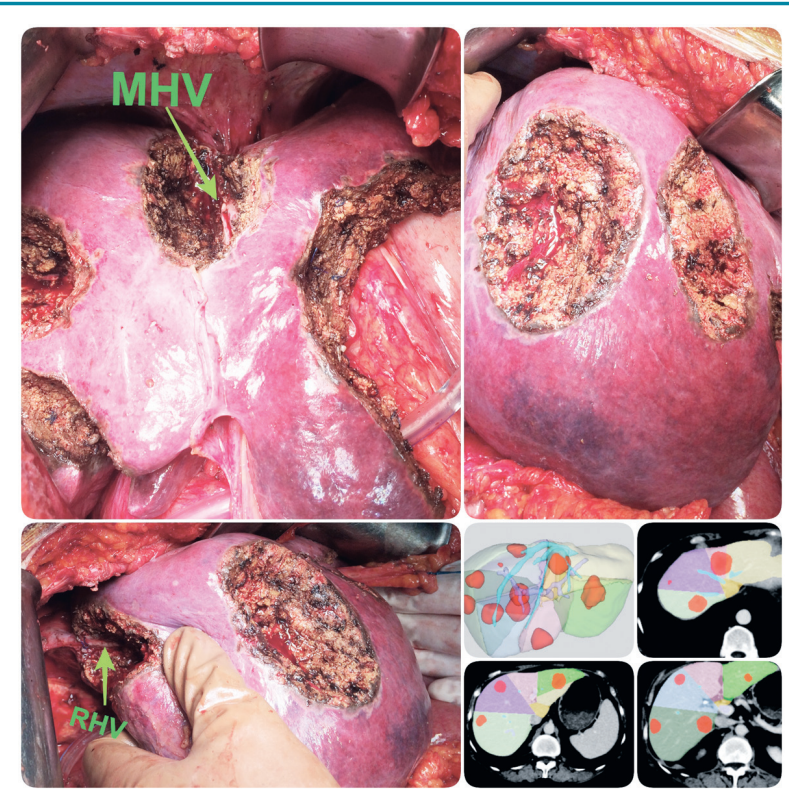

Рис. 2. Фото оперованої печінки та зображення реконструкції КТ. Білобарні метастази в печінку (№ 9), у 2 випадках метастатичні вогнища контактують з магістральними судинами в зоні кавальних воріт печінки (RHV - права печінкова вена, MHV - серединна печінкова вена) без ознак інвазії

що виникає в 4-16\% випадків [10]. Отже, хірургічна стратегія безпосередньо впливає на можливість адекватного системного лікування таких пацієнтів в ад’ювантному режимі. Крім того, за даними останніх метааналізів, застосування великих резекцій супроводжується ризиком виконання R1 у $30 \%$ [11]. Тому ми вважаємо, що паренхімозберігаючий підхід у поєднанні з інтраопераційною УЗ-навігацією, орієнтування в 3D-анатомії судинних структур 1-3-го порядку та застосування vascular detachment дають можливість підвищити шанси кожного хворого в отриманні хірургічного лікування.

3 нашої точки зору, описаний підхід є альтернативою у випадках центрально локалізованих метастатичних вогнищ (у межах портальних чи кавальних воріт печінки). За умов дотримання класичного хірургічного алгоритму вимога широкого краю відступу від тканини метастатичного вогнища, що контактує, без ознак істинного вростання в стінку устя глісонових структур 1-го чи 2-го порядку, а також устя головних печінкових вен, незворотньо змушує хірургів виконувати «великі» резекції печінки. Така тактика достовірно підвищує ризики гострої

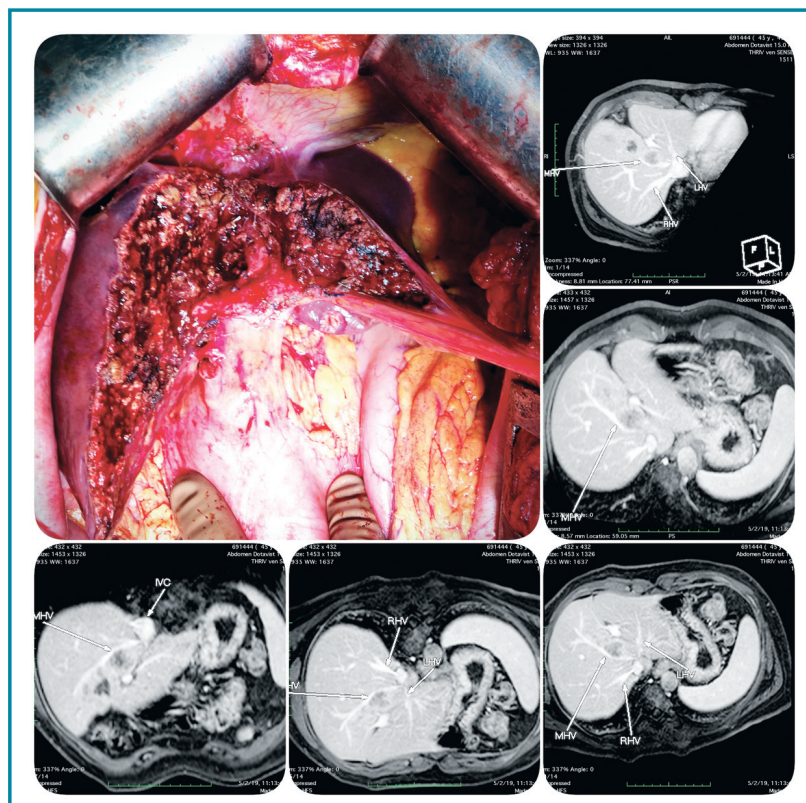

Рис. 3. Фото оперованої печінки та зображення реконструкції МРТ. Виконана анатомічна резекція 4-го сегмента печінки, розширеної на резекцію серединної печінкової вени (MHV). Застосували методику vascular detachment узоні глісонових структур 1-го та 2-го порядку до лівої частки печінки

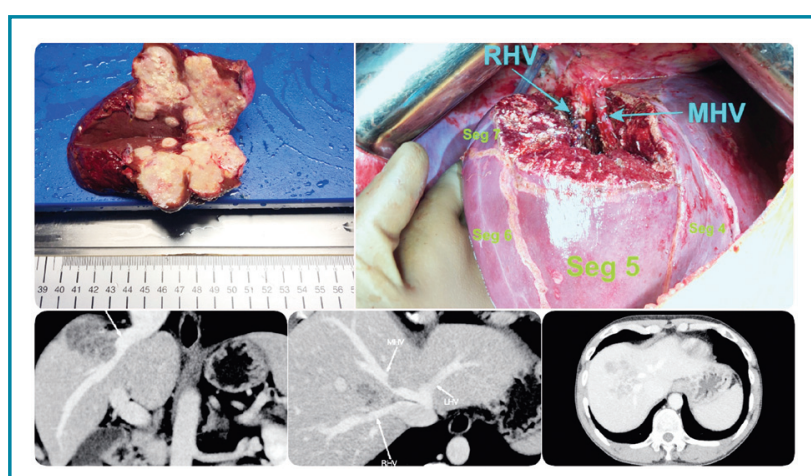

Рис. 4. Фото оперованої печінки та зображення реконструкції МРТ. Метастатичневогнище в проєкції кавальнихворіт, що має неправильну форму, заміщує собою паренхіму 8-го сегмента із судинним контактом до правої та серединної печінкових вен (RHV, MHV). Виконана анатомічна резекція 8-го сегмента з лінійною резекцією RHV та vascular detachment MHV

печінкової недостатності, оскільки small future liver remnant volume - головна причина смерті хворих при резекціях печінки, тоді як штучна стимуляція гіпертрофії (емболізація чи лігування портальної вени) несуть в собі приховані ризики пасивної стимуляції росту прихованих мікрометастазів [12]. Свідчення на користь можливої ініціації неконтрольованого пухлинного росту на фоні процесів хронічного запалення чи штучної активації механізмів гіпертрофії публікуються ще з 1980-х років та досі активно вивчаються як в умовах експерименту, так і в клініці (трансплантологія) [13].

Отримані нами результати виживаності демонструють референтні світовим значення для хворих як із центрально розташованими метастатичними вогнищами, так і з їх периферичною локалізацією. Крім того, застосована хірургічна тактика не спричинила підвищення рівня післяопераційних ускладнень чи смертності, незважаючи на свою технічну складність. У групі центральних резекцій була зареєстрована більш довготривала ішемія внаслідок використання маневру Прінгла та у ній частіше виконували гемотрансфузію. 


\section{висновок}

Паренхімозберігаюча хірургія в рамках мультикомпонентної стратегії є безпечною та ефективною з онкологічної точки зору для пацієнтів з КРР та білобарним метастатичним ураженням печінки. Адаптація паренхімозберігаючої хірургічної стратегії у хворих із метастатичним ураженням важкодоступних сайтів печінки забезпечила референтну 3-річну виживаність до периферичних вогнищ (38 та 42\% відповідно, $\mathrm{p}=0,44)$.

Вважаємо, що застосування R1 vascular detachment у поєднанні з сучасними схемами поліхіміотерапії може бути альтернативним методом, який зменшить когорту нерезектабельних хворих із білобарним метастатичним ураженням печінки.

\section{КОНФЛІКТ ІНТЕРЕСІВ ТА НЕДОЛІКИ}

Жоден з авторів статті не має конфлікту інтересів. Це дослідження виконане в рамках ретроспективного аналізу. Вважаємо за необхідне виконати аналіз безрецидивної виживаності в групах дослідження з метою оцінки онкологічної безпеки методу R1 vascular detachment. Також вважаємо, що такий підхід потребує вивчення в рамках рандомізованого дослідження.

\section{СПИСОК ВИКОРИСТАНОЇ ЛІТЕРАТУРИ}

1. Pawlik, T. M., Scoggins, C. R., Zorzi, D., Abdalla, E. K., Andres, A., Eng, C. ...Vauthey, J.-N. (2005). Effect of surgical margin status on survival and site of recurrence after hepatic resection for colorectal metastases. Ann Surg, 241(5), 715-724. doi: 10.1097/01.sla.0000160703.75808.7d

2. D'Angelica, M. I. (2017). Positive Margins After Resection of Metastatic Colorectal Cancer in the Liver: Back to the Drawing Board? Ann Surg Oncol, 24(9), 2432-2433. doi: 10.1245/s10434-017-5908-1.

3. Sadot, E., Groot Koerkamp, B., Leal, J. N., Shia, J., Gonen, M., Allen, P. J., ...D'Angelica, M. I. (2015). Resection margin and survival in 2368 patients undergoing hepatic resection for metastatic colorectal cancer: surgical technique or biological surrogate? Ann Surg, 262(3), 476-485. doi: 10.1097/SLA.0000000000001427.

4. Wang, J., Margonis, G. A., Amini, N., Andreatos, N., Yuan, C., Damaskos, C. Weiss, M. J. (2018). The Prognostic Value of Varying Definitions of Positive Resection Margin in Patients with Colorectal Cancer Liver Metastases. J Gastrointest Surg. 22(8), 1350-1357. doi: 10.1007/s11605-018-3748-3.

5. Alvarez, F. A., Sanchez Claria, R., Oggero, S., \& de Santibañes, E. (2016) Parenchymal-sparing liver surgery in patients with colorectal carcinoma liver metastases. World J Gastrointest Surg, 8(6), 407-423. doi: 10.4240/wjgs.v8.i6.407.

6. Torzilli, G., Serenari, M., Viganò, L., Cimino, M., Benini, C., Massani, M., ...Jovine, E. (2019). Outcomes of enhanced one-stage ultrasound-guided hepatectomy for bilobar colorectal liver metastases compared to those of ALPPS: a multicenter case-match analysis. HPB (Oxford), pii: S1365-182X(19)30512-X. doi: 10.1016/j.hpb.2019.04.001.

7. Krausch, M., Raffel, A., Anlauf, M., Schott, M., Lehwald, N., Krieg, A., ...Knoefel, W. T. (2014). "Cherry picking", a multiple non-anatomic liver resection technique, as a promising option for diffuse liver metastases in patients with neuroendocrine tumours. World J Surg, 38(2), 392-401. doi: 10.1007/s00268-013-2267-3.

8. Torzilli, G., \& Cimino, M. M. (2017). Extending the Limits of Resection for Colorectal Liver Metastases ENHANCED ONE STAGE SURGERY. J Gastrointest Surg, 21(1), 187-189. doi: 10.1007/s11605-016-3250-8.

9. Adam, R., de Gramont, A., Figueras, J., Kokudo, N., Kunstlinger, F., Loyer, E., ..Påhlman, L. (2015). Managing synchronous liver metastases from colorectal cancer: a multidisciplinary international consensus. Cancer Treat Rev, 41(9), 729-741. doi: $10.1016 /$ j.ctrv.2015.06.006.

10. Narita, M., Oussoultzoglou, E., Bachellier, P., Jaeck, D., \& Uemoto, S. (2015). Post-hepatectomy liver failure in patients with colorectal liver metastases. Surg Today, 45(10), 1218-1226. doi: 10.1007/s00595-015-1113-7.

11. Viganò, L., Costa, G., Cimino, M. M., Procopio, F., Donadon, M., Del Fabbro, D., ...Torzilli, G. (2018). R1 Resection for Colorectal Liver Metastases: a Survey Questioning Surgeons about Its Incidence, Clinical Impact, and Management. J Gastrointest Surg, 22(10), 1752-1763. doi: 10.1007/s11605-018-3820-z.

12. Hoekstra, L. T., van Lienden, K. P., Verheij, J., van der Loos, C. M., Heger, M., \& van Gulik, T. M. (2013). Enhanced tumor growth after portal vein embolization in a rabbit tumor model. J Surg Res, 180(1), 89-96. doi: 10.1016/j.jss.2012.10.032.

13. Landskron, G., De la Fuente, M., Thuwajit, P., Thuwajit, C., \& Hermoso, M. A. (2014) Chronic inflammation and cytokines in the tumor microenvironment. J Immunol Res, 2014 149185. doi: $10.1155 / 2014 / 149185$.

\section{Мультикомпонентная стратегия хирургии \\ билобарного метастатического поражения печени колоректальным раком}

\section{А.А. Бурлака, А.А. Шудрак, О.В. Васильев, Е.А. Колесник}

Национальный институт рака, Киев

Резюме. Актуальность. До сих пор малоизученными остаются результаты паренхимосохраняющей стратегии при локализации метастатических образований в труднодоступных сайтах печени с точки зрения хирургической анатомии органа (правое венозное ядро, портальные и кавальные ворота печени, паракавальная и каудальная части 1-го сегмента). Цель. Изучить онкологическую и хирургическую безопасность паренхимосохраняющей хирургической стратегии у больных с метастатическим поражением труднодоступных сайтов печени. Материал и методы. Выполнен ретроспективный анализ результатов хирургического и комбинированного лечения больных с билобарным метастатическим поражением печени колоректальным раком. В зависимости от локализации метастатических очагов больных условно поделили на 2 группы: «периферические» $(\mathrm{n}=38)$, в которую отнесли пациентов с преимущественным поражением левой латеральной секции $(\operatorname{Seg} 2,3)$ и задней секции $(\operatorname{Seg} 6,7)$, спигелиевой части Seg 1 ; «центральные» $(\mathrm{n}=107)$ - больные с метастатическим поражением портальных и кавальных ворот печени, передней секции (Seg 5,8), 4-го сегмента, паракавальной части Seg 1. Результаты. Центральные резекции по принципам сохранения паренхимы печени требовали более частого использования принципов хирургии R1 vascular detachment, выполненных в 23,6 и 4,6\% случаев больным группы с центрально и периферически локализованными метастазами $(\mathrm{p}<0,001)$. Послеоперационные тяжелые осложнения ( $\geqslant$ III степени по классификации Clavien - Dindo) составили 7,8 и 4,6\% соответственно для групп сравнения $(\mathrm{p}=0,23)$. Уровень общей кумулятивной 3 -летней выживаемости в группах больных составил 38 и $42 \%$ соответственно для группы центрально и периферически расположенных метастатических очагов $(\mathrm{p}=0,44)$. Выводы. Считаем, что применение R1 vascular detachment в сочетании с современными схемами полихимиотерапии может быть альтернативным методом, который уменьшит когорту нерезектабельных больных с билобарным метастатическим поражением печени.

Ключевые слова: R1 vascular detachment; паренхимосохраняющая резекция печени; интраоперационная ультразвуковая навигация; труднодоступные сайты печени.

Multicomponent surgical strategy in patients with bilobar colorectal cancer liver metastases

\section{A.A. Burlaka, A.A. Shudrak, O.V. Vasilyev, O.O. Kolesnik}

National Cancer Institute, Kyiv

Summary. Objective. The results of the parenchyma preserving surgical strategy for colorectal cancer metastatic lesions in hard to reach liver sites from the point of view of the surgical anatomy of the organ (right venous core, portal and caval gates of the liver, S1) are still poorly discovered. Aim. To study the oncologic and surgical effect of parenchymal preserving surgical strategy in colorectal cancer patients with metastatic lesions in hard to reach liver sites. Material and methods. A retrospective analysis of colorectal cancer patients with metastatic lesions was performed. Depending on the localization of metastatic lesions, they were conditionally divided into 2 groups: «peripheral» $(n=38)$, which included patients with predominant lesions of the left lateral section and posterior section, spigel lobe of $\mathrm{S} 1$; and «central» $(\mathrm{n}=107)$ patients with metastatic lesions of the portal and caval gates of the liver, anterior section, S4, paracaval part of S1. Results. R1 vascular detachment, was performed in 23.6 and $4.6 \%$ of patients in the group with centrally and peripherally localized metastases, respectively $(p<0.001)$. Postoperative severe complications ( $\geqslant$ III grade according to the Clavien - Dindo classification) were 7.8 and $4.6 \%$, respectively $(\mathrm{p}=0.23)$. The overall 3 -year survival rate in groups was 38 and $42 \%$, respectively, for the centrally and peripherally located metastatic lesions $(\mathrm{p}=0.44)$. Conclusions. We believe that the use of R1 vascular detachment in combination with current chemotherapy regimens may be an alternative method that will reduce the cohort of unresectable colorectal cancer patients with metastatic lesions in hard to reach liver sites.

Key words: R1 vascular detachment; parenchyma preserving liver resection; intraoperative ultrasound navigation; hard to reach liver sites.

Адреса:

Бурлака Антон Анатолійович

03022, Київ, вул. Ломоносова, 33/43

Національний інститут раку

E-mail: nir.burlaka@gmail.com 